\title{
Peri-articular diseases of the hip: emerging frontiers in arthroscopic and endoscopic treatments
}

\author{
A. Aprato $\cdot$ N. Jayasekera $\cdot$ A. Bajwa $\cdot$ R. N. Villar
}

Received: 27 November 2012 / Accepted: 9 July 2013/Published online: 28 July 2013

(c) The Author(s) 2013. This article is published with open access at Springerlink.com

\begin{abstract}
The precise diagnosis of both intra and extracapsular disease of the hip is now possible because of commonly available advanced diagnostic imaging techniques. An increasing number of reports in the orthopedic literature describe new endoscopic and arthroscopic techniques to address peri-articular pathology of the hip. The purpose of this paper is to review current techniques in the management of extra-articular hip conditions.
\end{abstract}

Keywords Peri-articular hip diseases · Hip arthroscopy · Hip endoscopy

\section{Background}

Hip arthroscopy has gained considerable popularity in the past decade because of an increasing understanding of femoroacetabular impingement (FAI) [1]. At present FAI is the most common indication for hip arthroscopy, though several other intra-articular conditions of the hip such as loose bodies, labral tears and chondral lesion are also commonly treated [2]. Recent orthopedic literature has focused mainly on these hip conditions, but advances in diagnostic imaging techniques now allow for the precise diagnosis of extra-capsular disease of the hip, often with associated intra-capsular pathology. Furthermore, an increasing number of surgeons have recently described

A. Aprato $\cdot$ N. Jayasekera $\cdot$ A. Bajwa $\cdot$ R. N. Villar

The Richard Villar Practice, Spire Cambridge Lea Hospital, Impington, Cambridge CB24 9EL, UK

\section{A. Aprato $(\square)$}

Corso Lanza 72, 10131 Turin, Italy

e-mail: ale_aprato@hotmail.com arthroscopic and endoscopic techniques in addressing periarticular conditions of the hip [3].

The purpose of this paper is to review current techniques in the management of extra-articular hip conditions.

For academic purposes we divide peri-articular hip diseases according to the anatomical compartment involved (Fig. 1). In the following paragraphs we describe each pathological anatomic structure and appropriate arthroscopic or endoscopic treatment.

Internal snapping hip syndrome and psoas tendon impingement

The internal snapping hip syndrome may be caused by the iliopsoas tendon [4]. The snapping usually results as the hip is extended from a flexed position, usually from more than $90^{\circ}$ of flexion. In this position the iliopsoas tendon may snap over the iliopectineal eminence or the femoral head.

Other causes of snapping should be excluded: the snap could be produced by the iliotibial band snapping over the greater trochanter, due to intra-articular pathology, such as loose bodies or labral tears [4]. This is no longer referred to as a snapping hip because the diagnosis of intra-articular pathology is now more accurate with MRA [5].

Symptoms and clinical examination of external snapping syndrome will be described in the following paragraphs, and ultrasound examination can verify the snap between greater trochanter and iliopsoas.

Although the internal snapping phenomenon can't be demonstrated directly with magnetic resonance arthrography (MRA), magnetic resonance imaging may frequently report changes within the iliopsoas tendon and bursa [5].

Asymptomatic internal snapping of the hip may occur in up to $10 \%$ of the general population. It is considered within normal variance and is thus managed conservatively [4]. 


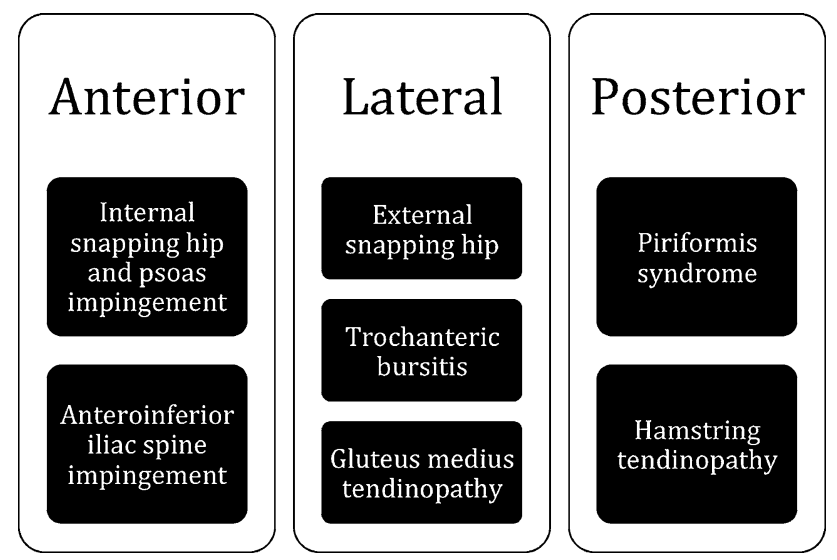

Fig. 1 Anatomic classification

The symptomatic internal snapping hip syndrome defined by pain in the groin is, however, a separate matter. Physiotherapy is the first line of treatment even in this scenario [4], with arthroscopic treatment reserved for those in whom symptoms persist.

The iliopsoas tendon itself may cause an impingement. Domb [6] described a specific pattern of hip pain associated with a labral injury at the 3 o'clock or direct anterior position with no evidence of FAI, bony abnormality, trauma, or any other known cause of labral injury. Clinical presentation is usually an anterior hip pain and pain exacerbated with active flexion, while some patients also experience a snapping sensation. Iliopsoas tenderness, a positive impingement test, and pain or apprehension with resisted straight leg raise may be apparent at physical examination. MRA may show isolated injury to the labrum at the 3 o'clock position. In some cases, this injury may be associated with an inflamed appearance of the iliopsoas tendon.

While some patients experience incomplete pain relief with intra-articular injection, many found more complete relief after a psoas injection. Arthroscopic release may be performed in patients unresponsive to corticosteroid injection.

Open procedures are reported in the orthopedic literature [7-11] and more recently two distinct arthroscopic techniques [12] have been described for release of the iliopsoas tendon. Tendon release may be performed at the level of the hip joint through an anterior capsulotomy (trans-capsular) [12] (Fig. 2) or at its distal insertion to the lesser trochanter within the iliopsoas bursa (Figs. 3, 4) [12].

The trans-capsular technique allows for release of the tendon via the central or peripheral compartment. The later, described by Ilizaliturri [12], addresses the iliopsoas tendon immediately anterior to the hip capsule in the space between the zona orbicularis and anterior labrum proximal,

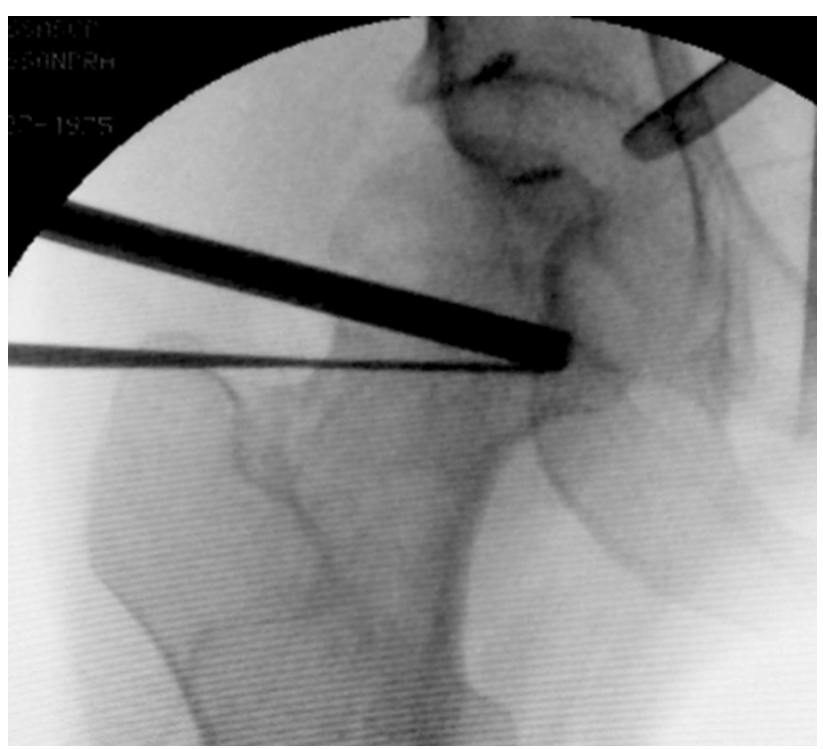

Fig. 2 Image intensifier view of transcapsular psoas tendon release

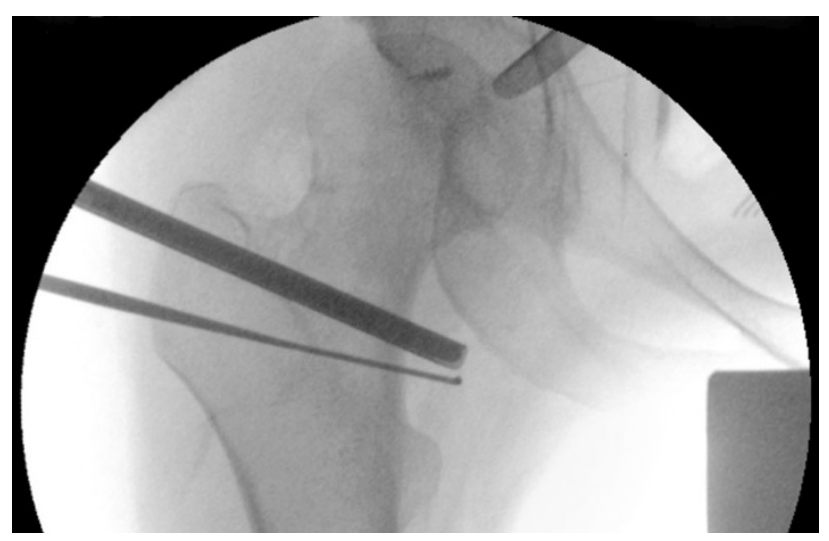

Fig. 3 Image intensifier view of psoas tendon release at the level of lesser trochanter

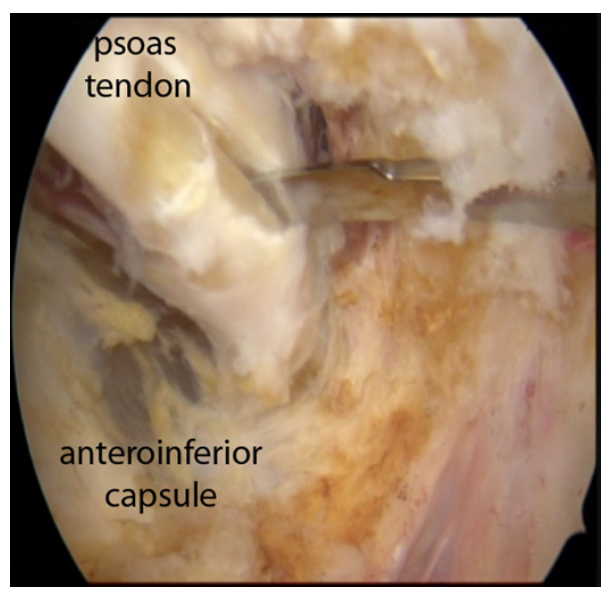

Fig. 4 Arthroscopic view of psoas tendon release trough peripheral compartment 
and anterior to the medial synovial fold. A capsulectomy is performed at this level to gain access to the iliopsoas tendon; synovial tissue from around the tendon may be debrided using a radiofrequency probe or an arthroscopic shaver.

Endoscopic release may also be performed at the lesser trochanter. A spinal needle is guided into position under image intensifier control, aiming for its tip to be located within the iliopsoas insertion. This manoeuvre may be aided by "palpating" the medial aspect of the femur with the tip of the spinal needle as it lands on the lesser trochanter. The needle may then be substituted by an arthroscopic cannula prior to the introduction of a $30^{\circ}$ arthroscope. A second working portal is created by triangulation toward the tip of the arthroscope inside the iliopsoas bursa. The image intensifier is used to confirm correct location of the radiofrequency probe prior to iliopsoas tendon release.

Trans-capsular tendon release presents a potential risk of joint instability due to the extensive capsulotomy, especially in patients with hyperlaxity. However, it may be more easily performed via the peripheral compartment. The orthopedic literature reports one paper in which the two techniques were compared, with the author finding no clinical difference in results. Published results of open and arthroscopic techniques are summarized in Table $1[4,6-$ 16]. Arthroscopic release appears to be successful and, in general, there are higher success rates and less recurrence with the endoscopic technique compared with open procedures.

\section{Anteroinferior iliac spine impingement}

The anterior inferior iliac spine (AIIS) represents the origin of the direct head of the rectus femoris tendon [17]. Avulsion of the AIIS has been described in the literature after traumatic injury and, if not adequately treated, could result in an anterior impingement against the distal femoral neck (Fig. 5) [17].

Patients usually describe a "grinding sensation" in flexion and rotation of their hip and pain with athletic activity and prolonged hip flexion. Physical examination confirms pain with hip flexion, internal rotation, and adduction and limited hip flexion [18]. Radiographs show a low AIIS, commonly due to prior traumatic avulsion [19].

Open treatment via a direct anterior approach to the AIIS and internal fixation has been described for selected cases [17]. Pan [18] described a 30-year-old man who presented with evidence of impingement between the femoral head-neck junction and an abnormally large anterior inferior iliac spine. Open resection of the hypertrophic anterior inferior iliac spine was performed, which produced full painless restoration of function of the hip
(Fig. 6). Larson published two papers describing three and ten cases, respectively, of AIIS or subspine impingement that he managed with arthroscopic decompression $[19,20]$. Matsuda [21] has also described arthroscopic management in a case of secondary symptomatic femoroacetabular impingement arising from an inferiorly malunited AIIS avulsion fracture.

Decompression may be performed using arthroscopy of the hip. The AIIS is easily identified by stripping the capsule over the AIIS with a combination of a shaver and burr. However, the authors [20] describe risk of detachment of the rectus femoris from its origin, owing to overzealous resection, which may in turn lead to a potential deficit in hip flexion. Results of open and endoscopic procedures are summarized in Table 2. More studies with larger cohorts and longer follow-ups are necessary to perform a more adequate evaluation of the role of endoscopic techniques in AIIS impingement.

\section{Greater trochanteric pain syndrome}

Greater trochanteric pain syndrome (GTPS) has an estimated incidence of 1.8 per 1,000 persons [22]. This syndrome includes 3 well-described entities: external coxa saltans, greater trochanteric bursitis, and gluteus medius and/or minimus tears. Although these disorders are often associated, for academic purposes they will be analyzed separately in the flollowing paragraphs [23].

\section{External snapping of the hip}

External snapping of the hip is caused by thickening of fibers of the iliotibial band [24], which snap over the greater trochanter with hip flexion and extension and, in more severe cases, with hip rotation. The diagnosis may be confirmed with ultra sound imaging [25]. The patient may be asymptomatic and reproduce the snapping voluntarily. In such cases exercises to stretch the iliotibial band are recommend. In the symptomatic patient, the first line of treatment is physiotherapy. If physiotherapy fails, endoscopic surgical release may be indicated. A recent systematic review [26] found traditional non-operative treatments to be effective in most refractory cases. Open iliotibial band release or lengthening has been the traditional surgical option to treat external snapping hip syndrome [27-31]. Ilizaliturri [32] has recently described a technique for endoscopic iliotibial band release performed under image intensifier control. He describes proximal and distal trochanteric portals through which either a Z- or a diamond-shaped release is performed (Figs. 7, 8). Where indicated, the additional treatment of gluteus medius tear, trochanteric bone prominence or bursitis may be performed as described subsequently. Results of open and endoscopic 
Table 1 Literature reports on treatments for internal snapping hip syndrome and psoas tendon impingement

\begin{tabular}{|c|c|c|c|c|c|}
\hline $\begin{array}{l}\text { First } \\
\text { author }\end{array}$ & References & Technique & $\begin{array}{l}\text { Number } \\
\text { of hips }\end{array}$ & $\begin{array}{l}\text { Follow- } \\
\text { up } \\
\text { (months) }\end{array}$ & Results \\
\hline Taylor & [7] & Open release (medial approach) & 17 & 17 & $\begin{array}{l}31 \% \text { residual pain, } 38 \% \text { recurrent snapping, } 12.5 \% \\
\text { had persistent weakness with hip flexion }\end{array}$ \\
\hline Jacobson & [8] & Open Z plasty & 20 & 25 & $\begin{array}{l}19 \text { reductions of snapping frequency, } 14 \text { no snapping, } 2 \\
\text { required reoperation, } 3 \text { subjective weakness }\end{array}$ \\
\hline Dobbs & [9] & Open Z plasty (iliofemoral incision) & 11 & 48 & $\begin{array}{l}11 \text { had complete pain relief, no patient had detectable } \\
\text { loss of hip flexion strength, } 1 \text { patient had a recurrence } \\
\text { of the snapping, and } 2 \text { patients had a transient decrease } \\
\text { in sensation over the anterolateral thigh due to injury } \\
\text { of the lateral femoral cutaneous nerve }\end{array}$ \\
\hline Gruen & {$[10]$} & Open Z plasty (ilioinguinal incision) & 11 & 36 & $\begin{array}{l}58 \% \text { complete resolution of their hip pain, } 17 \% \text { had } \\
\text { recurrence, } 25 \% \text { improved, } 5 \text { had postoperative } \\
\text { subjective weakness. No complications related to the } \\
\text { wound or surgical approach }\end{array}$ \\
\hline Hoskins & {$[11]$} & $\begin{array}{l}\text { Open tendon lengthening } \\
\text { (iliofemoral incision) }\end{array}$ & 92 & 65 & $\begin{array}{l}12 \% \text { recurrence of snapping within } 3 \text { months and } \\
\text { another } 10 \% \text { after } 3 \text { months, } 12 \% \text { had surgical } \\
\text { incision related complications }\end{array}$ \\
\hline Byrd & [4] & $\begin{array}{l}\text { Endoscopic release at lesser } \\
\text { trochanter }\end{array}$ & 9 & 20 & All patients pain free, no recurrence \\
\hline Ilizaliturri & {$[12]$} & $\begin{array}{l}\text { Endoscopic release at lesser } \\
\text { trochanter (10) and endoscopic } \\
\text { transcapsular (9) (randomized) }\end{array}$ & 19 & 20 & $\begin{array}{l}\text { Improvements in WOMAC scores were statistically } \\
\text { significant in both groups, and no difference was found } \\
\text { in postoperative WOMAC results between groups. No } \\
\text { complications were seen }\end{array}$ \\
\hline Anderson & {$[13]$} & $\begin{array}{l}\text { Endoscopic release at lesser } \\
\text { trochanter (athletes) }\end{array}$ & 12 & 9 & $\begin{array}{l}\text { Preoperative hip scores averaged } 41 \text { and } 44 \text { points for } \\
\text { the competitive and recreational athletes, respectively, } \\
\text { at } 12 \text { months, } 96 \text { and } 97 \text { points, and none had } \\
\text { recurrence of their snapping or pain }\end{array}$ \\
\hline Flanum & {$[14]$} & $\begin{array}{l}\text { Endoscopic release at the lesser } \\
\text { trochanter }\end{array}$ & 6 & 12 & $\begin{array}{l}38 \text { points average Harris hip scores increase, no } \\
\text { recurrence }\end{array}$ \\
\hline Wettstein & {$[15]$} & $\begin{array}{l}\text { Endoscopic release (preserving } \\
\text { iliacus muscle) transcapsular }\end{array}$ & 9 & 3 & $\begin{array}{l}\text { No complications, hip flexion strength was restored to } \\
\text { normal within } 3 \text { months }\end{array}$ \\
\hline Ilizaliturri & {$[16]$} & $\begin{array}{l}\text { Endoscopic release at the lesser } \\
\text { trochanter }\end{array}$ & 7 & 21 & $\begin{array}{l}\text { All the patients were relieved of their painful snapping } \\
\text { symptoms, average WOMAC score improved from } \\
82.5 \text { to } 91 \text { points. The only complication seen was loss } \\
\text { of flexion strength in all patients }\end{array}$ \\
\hline Domb & {$[6]$} & $\begin{array}{l}\text { Endoscopic tenotomy and either } \\
\text { labral debridement or repair }\end{array}$ & 25 & 21 & $\begin{array}{l}\text { Mean preoperative HHS, ADL HOS, and Sport HOS } \\
\text { scores were } 61.64,73.94 \text {, and } 51.63 \text {, respectively, the } \\
\text { mean post-operative scores were } 86.06,88.21 \text {, and } \\
\text { 72.01, respectively }\end{array}$ \\
\hline
\end{tabular}

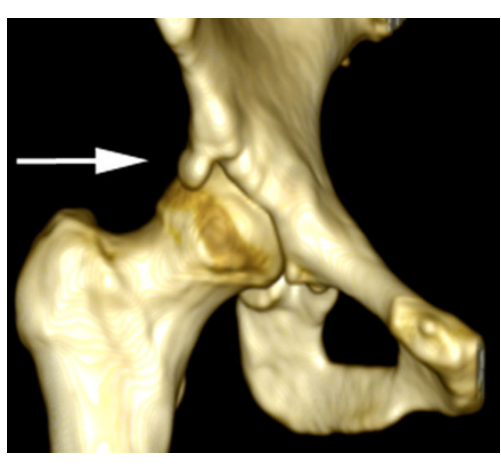

Fig. 5 Pre-operative 3-D CT reconstruction image of anteroinferior iliac spine impingement lesion

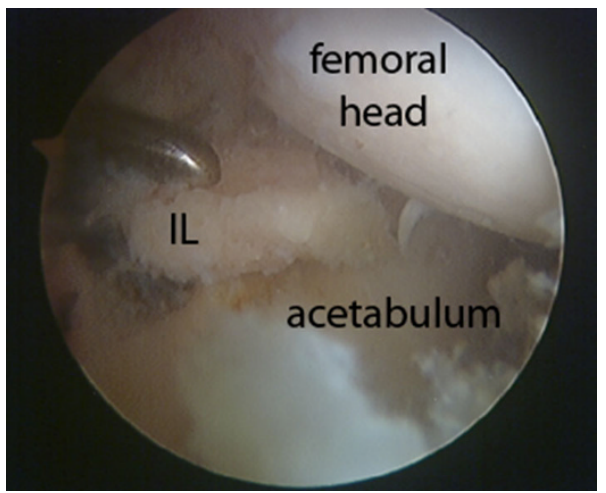

Fig. 6 Arthroscopic view at excision of anteroinferior iliac spine impingement lesion (IL) 
Table 2 Literature reports on treatments for anteroinferior iliac spine impingement

\begin{tabular}{|c|c|c|c|c|}
\hline $\begin{array}{l}\text { First } \\
\text { author }\end{array}$ & References & Procedure & $\begin{array}{l}\text { Number } \\
\text { of treated } \\
\text { hips }\end{array}$ & Results \\
\hline Rajasekhar & {$[17]$} & $\begin{array}{l}\text { Resection of the hypertrophic AIIS } \\
\text { (patient 1), } 1 \text { fixation of AIIS } \\
\text { fragment (patient 2) }\end{array}$ & 2 & $\begin{array}{l}\text { Patient 1: at } 2.5 \text { years follow-up asymptomatic and returned to } \\
\text { his normal sporting activity. Patient } 2: \text { at } 1 \text { year follow-up } \\
\text { pain free, able to participate actively in sport }\end{array}$ \\
\hline Pan & {$[18]$} & $\begin{array}{l}\text { Resection of the hypertrophic anterior } \\
\text { inferior iliac spine }\end{array}$ & 1 & Full painless restoration of function of the hip \\
\hline Larson & [19] & Arthroscopic decompression & 3 & $\begin{array}{l}\text { Average MHHS: } 75.6 \text { points pre op and } 93.7 \text { post op; average } \\
\text { VAS } 6.2 \text { pre op and } 1.1 \text { post op }\end{array}$ \\
\hline Hetsroni & {$[20]$} & Arthroscopic decompression & 10 & $\begin{array}{l}\text { At a mean follow-up time of } 14.7 \text { months, the modified Harris } \\
\text { hip score improved from } 64.18 \text { before surgery to } 98.2 \text { points }\end{array}$ \\
\hline Matsuda & {$[21]$} & Arthroscopic spinoplasty & 1 & $\begin{array}{l}\text { At } 18 \text { months follow-up returned to football, a nonarthritic hip } \\
\text { score of } 98 \text { points, nonrestrictive heterotopic ossification }\end{array}$ \\
\hline
\end{tabular}

procedures for lateral hip pathologies are shown in Table 3. According to Ilizariturri's review [3], endoscopic surgery in the peritrochanteric space seems safe, reproducible, and allows for the successful treatment of snapping hip syndromes.

\section{Trochanteric bursa inflammation}

Inflammation of the trochanteric bursa is the most common cause of pain over the lateral aspect of the hip [23]. Symptoms may be aggravated by pressure over the area, weight bearing, and resisted external rotation in supine (with hip flexed to $90^{\circ}$ ) and prone (with hip extended) positions.

The improved accuracy of MRI has allowed for more precise diagnosis of bursitis [41]. MRI is also helpful to rule out gluteus medius tears that may present with similar symptoms [41].

The first line of treatment is conservative, with appropriate anti-inflammatory therapy and lifestyle modification [42]. Corticosteroid injections have been commonly utilized in the presence of failed conservative treatment. Bursitis often responds favorably to conservative

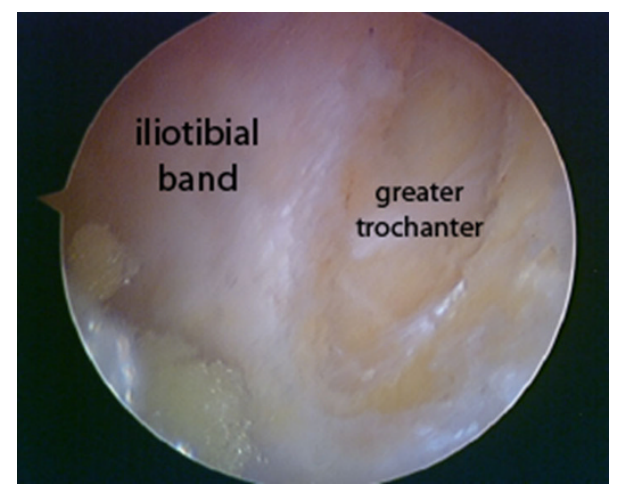

Fig. 7 Endoscopic view of iliotibial band $\mathrm{Z}$ lengthening

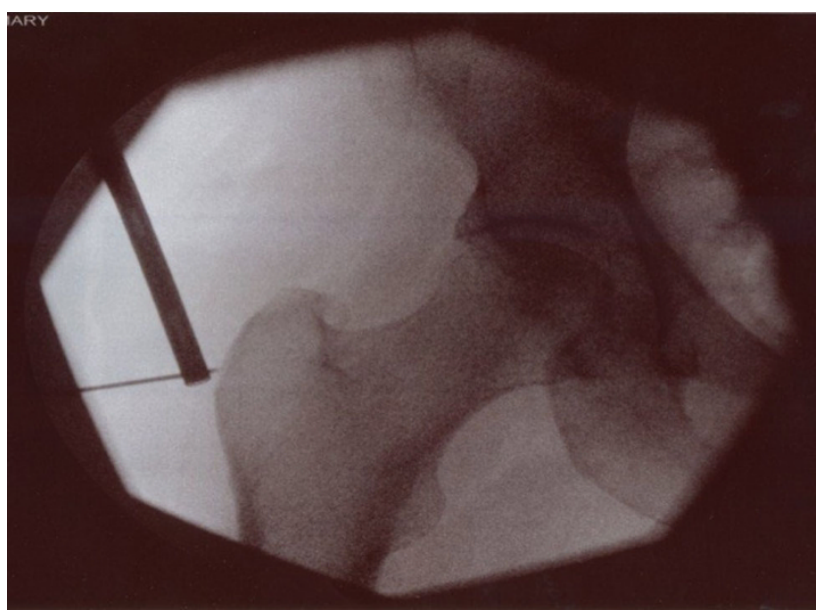

Fig. 8 Image intensifier view of endoscopic portal placement for trochanteric procedures

management [43]. When the bursitis is refractory to conservative treatment and to corticosteroid injection, surgical bursectomy should be considered [43].

Endoscopic bursectomy [34-37] may be performed in either the lateral decubitus or supine positions [42]. In the lateral position, bursectomy can be performed through a proximal portal $2-\mathrm{cm}$ posterior to the tip of the trochanter and a distal portal at the postero-inferior margin of the bursa. A 4-mm, $30^{\circ}$ arthroscope can be used to examine the bursa through the posterior distal portal. The leg is abducted to relax the soft tissues and maximize distention in the bursa. Debridement can be performed with a 4-mm full-radius resector placed in the proximal portal. When the bursectomy is complete, the arthroscope and shaver are switched for a final check. If there is an associated prominence of the greater trochanter, the bone can be shaved with a 5.5-mm burr (Fig. 9). In our experience the lateral position technique lends itself more readily to bursectomy with portals made through the tensor fascia 
Table 3 Literature reports on treatments for external snapping of the hip, trochanteric bursa inflammation and gluteus medius diseases

\begin{tabular}{|c|c|c|c|c|c|}
\hline $\begin{array}{l}\text { First } \\
\text { author }\end{array}$ & References & Technique & $\begin{array}{l}\text { Number } \\
\text { of hips }\end{array}$ & $\begin{array}{l}\text { Follow-up } \\
\text { (months) }\end{array}$ & Results and complications \\
\hline Provencher & {$[27]$} & Open Z plasty & 9 & 23 & $\begin{array}{l}\text { All patients had complete resolution of the snapping } \\
\text { hip, } 1 \text { returned to full unrestricted activities but no } \\
\text { residual snapping }\end{array}$ \\
\hline White & {$[28]$} & $\begin{array}{l}\text { Open vertical incision and multiple } \\
\text { transverse cuts }\end{array}$ & 16 & 32.5 & $\begin{array}{l}14 \text { asymptomatic patients after release ( } 2 \text { hips needed } \\
\text { a second release) }\end{array}$ \\
\hline Faraj & [29] & Open Z plasty & 11 & 12 & Good results, 3 had problems due to scar sensitivity \\
\hline Fery & {$[30]$} & $\begin{array}{l}\text { Open cross cut and inverted flap } \\
\text { suture }\end{array}$ & 35 & 84 & $\begin{array}{l}30 \% \text { successful results, } 30 \% \text { had a recurrence of } \\
\text { symptoms and over } 60 \% \text { continued to experience } \\
\text { pain }\end{array}$ \\
\hline Govaert & [31] & $\begin{array}{l}\text { Open longitudinal release of the } \\
\text { iliotibial band combined with } \\
\text { excision of the trochanteric bursa }\end{array}$ & 12 & 23.5 & $\begin{array}{l}\text { The mean difference between the pre- and } \\
\text { postoperative Merle d'Aubigné and Postel scores } \\
\text { was } 11.7 \text { points; } 6 \text { excellent results, } 5 \text { good and } 1 \\
\text { poor. One screw removal for pain, one surgically } \\
\text { drained hematoma }\end{array}$ \\
\hline Ilizaliturri & {$[32]$} & Endoscopic diamond shape defect & 11 & 25 & 1 residual nonpainful snapping, 10 excellent results \\
\hline Wiese & {$[33]$} & $\begin{array}{l}\text { Endoscopic bursectomies and in } 4 \\
\text { coxa saltans suture of the iliotibial } \\
\text { tract to the greater trochanter }\end{array}$ & 37 & 25 & $\begin{array}{l}32.5 \text { points was the average Japanese orthopedic } \\
\text { association score improvement; VAS improved } \\
\text { from } 7.2 \text { to } 3.8 \text { points. Four patients developed } \\
\text { hematoma }\end{array}$ \\
\hline Baker & [34] & Endoscopic bursectomy & 30 & 26.1 & $\begin{array}{l}\text { VAS improved from } 7.2 \text { to } 3.1 \text {, mean Harris hip } \\
\text { scores improved from } 51 \text { to } 77 \text { points, one seroma } \\
\text { and one subsequent open bursectomy }\end{array}$ \\
\hline Fox & {$[35]$} & Endoscopic bursectomy & 27 & $\begin{array}{l}60 \text { (only } \\
\text { for } 22 \\
\text { patients) }\end{array}$ & $\begin{array}{l}24 \text { good or excellent results without complications, } \\
2 \text { recurrences, } 1 \text { unsatisfied }\end{array}$ \\
\hline Bradley & {$[36]$} & Endoscopic bursectomy & 2 & 7 & $\begin{array}{l}\text { Immediate symptomatic improvement, returned to } \\
\text { competitive basketball with occasional aching in } \\
\text { his right hip }\end{array}$ \\
\hline Farr & {$[37]$} & $\begin{array}{l}\text { Endoscopic bursectomy and } \\
\text { concomitant iliotibial band release } \\
\text { under local anesthesia }\end{array}$ & 2 & 41 & All excellent results, no recurrence \\
\hline Kandemir & {$[38]$} & $\begin{array}{l}\text { Endoscopic excision of gluteus } \\
\text { medius/minimus calcifications }\end{array}$ & 1 & 3 & $\begin{array}{l}\text { Symptom-free without limitation of any activity, } \\
\text { normal abduction strength }\end{array}$ \\
\hline Voos & [39] & $\begin{array}{l}\text { Endoscopic repair of gluteus medius/ } \\
\text { minimus tears }\end{array}$ & 10 & 25 & $\begin{array}{l}10 \text { complete resolution of pain; no adverse } \\
\text { complications. Seven of } 10 \text { patients said their hip } \\
\text { was normal, and } 3 \text { said their hip was nearly normal }\end{array}$ \\
\hline Davies & {$[40]$} & $\begin{array}{l}\text { Open suture of torn abductors with } \\
\text { soft-tissue anchors in the greater } \\
\text { trochanter }\end{array}$ & 16 & 12 & $\begin{array}{l}4 \text { re-ruptures, } 1 \text { deep infection. In the remaining } 11 \\
\text { patients there were statistically significant } \\
\text { improvements in VAS and Oxford hip score }\end{array}$ \\
\hline
\end{tabular}

lata, and a Z-shaped fasciotomy performed if working space is inadequate. Strauss [42] described an endoscopic technique in the supine position, which preserves the fascia lata if a fasciotomy is not required. This technique has gained recent popularity and is performed through the anterior portal $(1 \mathrm{~cm}$ lateral to the anterior superior iliac spine and in the interval between the tensor fascia lata and the sartorius) and the distal peritrochanteric space portal (DPSP: midway between the tip of the greater trochanter and vastus tubercle along the posterior onethird of the greater trochanter midline). The leg is positioned in full extension and approximately $15^{\circ}$ of abduction. The shaver may then be placed within the peritrochanteric space through the DPSP to begin bursectomy. Evaluation of the iliotibial band, vastus lateralis insertion, gluteus minimus tendon and muscle and the insertion of the gluteus medius tendon at the greater trochanter may be performed. If a torn tendon is identified it may be repaired with use of suture anchors. Release of the iliotibial band is performed only if necessary for either external coxa saltans or abnormal contact across the greater trochanter. Results of endoscopic bursectomies are analyzed in Table 3 and showed a good efficacy and a low rate of complications. 


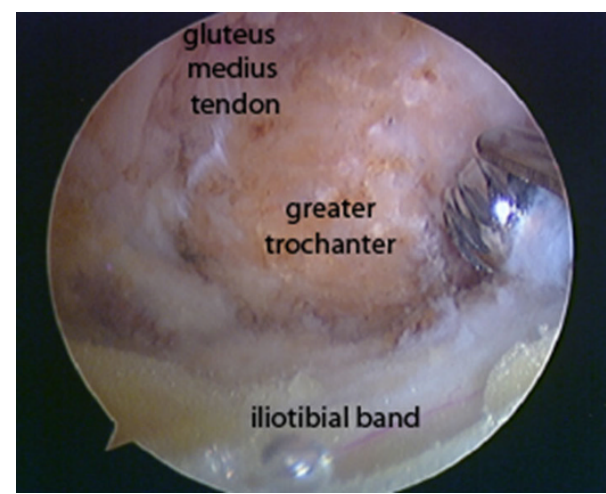

Fig. 9 Endoscopic view of greater trochanter prominence excision after trochanteric bursectomy

Gluteus medius diseases

When GTPS is caused by a gluteus medius tendinopathy, the majority of patients describe lateral-sided hip pain of insidious onset that is aggravated with weight bearing and resisted hip abduction [23]. Patients can often point to an exact point of pain that often occurs some centimeters proximal to the tip of greater trochanter. Good quality MRI is necessary to discriminate gluteal tears and trochanteric bursitis [41]. Once again, physiotherapy is the first line of treatment. When this fails, surgical treatment via various open [40] and more recently described endoscopic techniques is an option. Two endoscopic repair techniques of the gluteus tendon are described in the literature [39-44].

Voos et al. [39], describes a technique to repair gluteus tendon tears via the peritrochanteric compartment utilizing an anterior portal and a distal posterior portal.

Here the peritrochanteric space is typically distended with $50-70 \mathrm{~mm} \mathrm{Hg}$ of pressurization. The attachment site of the tendon at the greater trochanter (Fig. 10) is prepared with a full-radius shaver similar to preparation of the footprint for rotator cuff tears. Suture anchors can be placed into the footprint of the abductor tendons, the sutures are passed sequentially through the edges of the prepared gluteus medius tendon with a suture-passing device and tied.

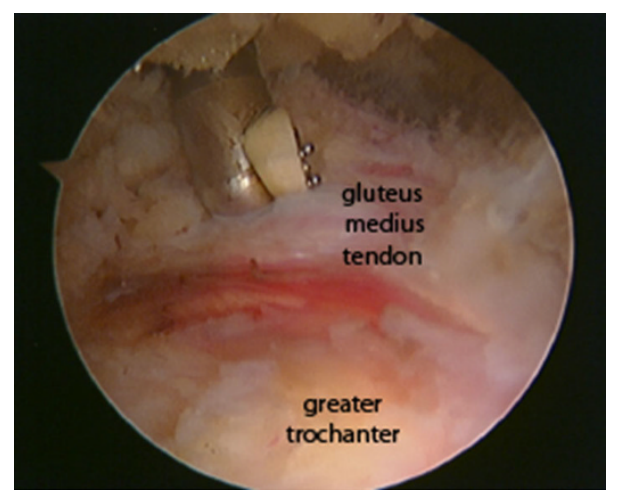

Fig. 10 Endoscopic view of gluteus medius tendinosis
Voos [39] reported complete resolution of symptoms in all ten patients in his series using this technique.

Domb [44] described another endoscopic technique of approaching the tendon through a longitudinal split in line with its fibers, in order to visualize and treat intra-substance tears without affecting the integrity and strength of the tendon itself. He describes the use of posterolateral and distal peritrochanteric portals. This technique results in a side-to-side repair of the longitudinal tendon split while firmly approximating the tendon to the footprint on the lateral facet.

As shown in Table 3, both techniques showed a good efficacy. According to our view, Domb's procedure [44] appears more challenging for the surgeon and aims to better preserve the tendon, which may be helpful in younger and more active patients. Studies with a larger cohort are necessary to give an evidence-based conclusion for the efficacy of these endoscopic techniques.

\section{Piriformis syndrome}

Piriformis syndrome results from sciatic nerve entrapment by the piriformis muscle [45]. It manifests as buttock pain and radicular-like pain associated with hip flexion movements with combined internal or external rotation. Piriformis syndrome often occurs after blunt trauma to the buttock with resultant hematoma formation and subsequent scarring between the sciatic nerve and external rotators [45]. Clinical tests such as Lasègue, Pace and Friberg sign are commonly positive and useful in the diagnosis of sciatic nerve entrapment.

Nerve conduction studies and MRI may confirm the clinical suspicion and exclude other causes of entrapment [46, 47].

Open surgical techniques have been shown to reduce pain associated with entrapment of the sciatic nerve caused by fibrous scar bands, vascular structures, or muscular anatomy [47-49].

Endoscopic treatment of piriformis syndrome under local anesthesia has been described [50-52]. As previously described, the portals for the peritrochanteric space are commonly utilized. A posterolateral auxiliary portal $(3 \mathrm{~cm}$ posterior and $3 \mathrm{~cm}$ superior to the greater trochanter) may be used in the presence of variation of sciatic nerve entrapment (atypical fibrous bands, hamstring tendons or fibrous scar bands extending from the trochanteric bursa to the sciatic nerve). Open and endoscopic results are compared in Table 4. Martin et al. [50] advocate endoscopic sciatic nerve decompression be performed only by hip arthroscopy experts and attribute their results to careful patient selection and surgical experience. Further studies are required to extend the indication of this procedure to less expert surgeons. 
Table 4 Literature reports on treatments for piriformis syndrome

\begin{tabular}{|c|c|c|c|c|c|}
\hline $\begin{array}{l}\text { First } \\
\text { author }\end{array}$ & References & Procedure & $\begin{array}{l}\text { Number } \\
\text { of hips }\end{array}$ & Follow-up & Results and complications \\
\hline Benson & {$[47]$} & $\begin{array}{l}\text { Open excision of post-traumatic } \\
\text { adhesions }\end{array}$ & 16 & 38 months & $\begin{array}{l}\text { Eleven excellent and four good results, one seroma } \\
\text { and one infected hematoma }\end{array}$ \\
\hline Fishman & [48] & Open nerve decompression & 43 & 16 months & $\begin{array}{l}68.8 \% \text { patients showed } 50 \% \text { or greater } \\
\text { improvement; mean improvement was } 68 \%\end{array}$ \\
\hline Filler & [49] & $\begin{array}{l}\text { Open nerve decompression }(3 \mathrm{~cm} \\
\text { incision, transgluteal approach) }\end{array}$ & 62 & Unstated & $\begin{array}{l}\text { Excellent outcome in } 58.5 \% \text {, good outcome in } \\
22.6 \% \text {, limited benefit in } 13.2 \% \text {, no benefit in } \\
3.8 \% \text {, and worsened symptoms in } 1.9 \%\end{array}$ \\
\hline Martin & {$[50]$} & $\begin{array}{l}\text { Endoscopic nerve decompression, } \\
\text { piriformis tendon release or by } \\
\text { hamstring tendon scarring }\end{array}$ & 35 & 1 year & $\begin{array}{l}\text { The mean postoperative MHHS increased to } 78.0 \\
\text { and VAS score decreased to } 2.4 \text {. The mean } \\
\text { postoperative MHHS increased to } 78.0 \text { and VAS } \\
\text { score decreased to } 2.4\end{array}$ \\
\hline Dezawa & {$[51]$} & $\begin{array}{l}\text { Endoscopic release of the piriformis } \\
\text { muscle under local anesthesia }\end{array}$ & 8 & Unstated & Good results in all patients \\
\hline Hwang & {$[52]$} & $\begin{array}{l}\text { Endoscopic incision, drainage of benign } \\
\text { cystic lesion on the sciatic nerve and } \\
\text { release of the piriformis tendon }\end{array}$ & 1 & 20 months & Good result, no recurrence \\
\hline
\end{tabular}

Hamstring avulsion and tendinopathy

Complete hamstring tendon rupture can occur during sports or slipping on a slick surface while hamstring tendinopathy is likely caused by a mixture of hereditary, structural, professional, and lifestyle factors [53]. The peak age for injury is the early to mid forties but it can occur also in the age range of 18-20 years [54]. In those cases the degree of trauma is typically more severe due to the external overload placed on the normal tendon. The majority of patients report being forced into a position of extreme hip flexion with the knee near or at full extension. A minority of patients describes the mechanism of injury to resemble "doing the splits". Patients often describe feeling a "pop" or tearing sensation in the hamstring/gluteal region. Patients usually find it difficult to extend the knee, presumably due to muscle spasm or irritation of the sciatic nerve. The presence of considerable swelling and ecchymosis along the posterior thigh may be seen in the acute setting and the patient may describe sciatica symptoms. Isometric testing of the hamstrings with knee flexed to $70^{\circ}$ may reveal significant deformity of the affected hamstring muscle belly owing to its distal retraction [54]. Positive patient history and clinical findings at physical examination should prompt further assessment with an MRI scan even when a complete avulsion is suspected clinically, as this would allow for precise delineation of the injury (Fig. 11) [55].

Surgical repair is indicated for patients in their youth, in athletes and those who have sustained acute complete tear of all three tendons with more than $2 \mathrm{~cm}$ retraction. Chronic tendinopathy on the other hand is commonly treated conservatively [56]. Surgical debridement of scar

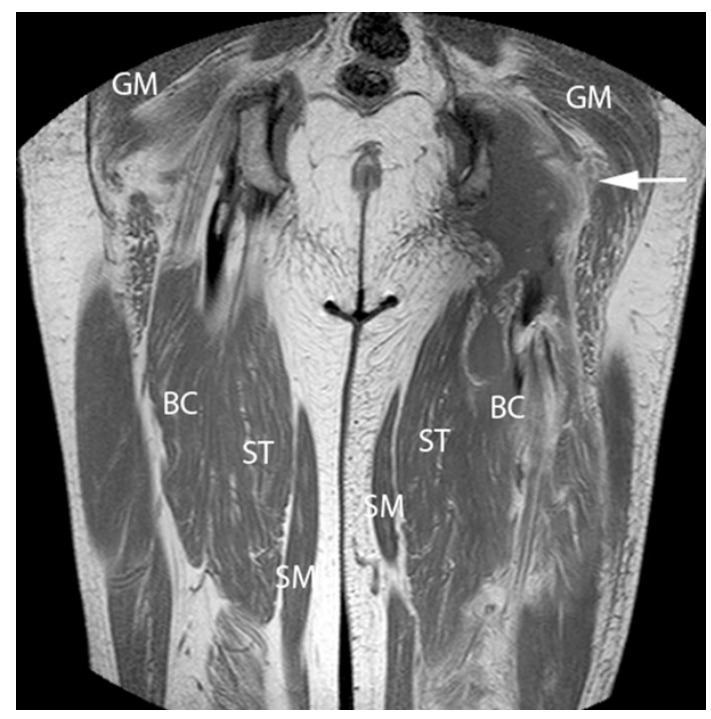

Fig. 11 MRI of left hamstring avulsion ( $G M$ gluteus maximus, $B C$ biceps femori, $S T$ semitendinosus, $S M$ semimembranosus)

may be indicated in cases where conservative treatment has failed. Open surgical techniques [56-59] for hamstring avulsions and tendinopathy are described in the literature, and recently Guanche described an endoscopic technique [60]. Endoscopic treatment is performed in the prone position through three portals. The first two portals are created $2 \mathrm{~cm}$ medial and lateral to the ischial tuberosity. The lateral portal is first used for a $30^{\circ}$ arthroscope. The tip and medial aspect of the ischium are delineated, then the lateral aspect is exposed with the use of radiofrequency. With the lateral aspect identified, the dissection continues anteriorly and laterally towards the sciatic nerve. A careful release of soft tissue is performed to cautiously mobilize 
Table 5 Literature reports on treatments for hamstring avulsion and tendinopathy

\begin{tabular}{|c|c|c|c|c|}
\hline $\begin{array}{l}\text { First } \\
\text { author }\end{array}$ & References & $\begin{array}{l}\text { Number } \\
\text { of hips }\end{array}$ & Treated lesions & Results \\
\hline Allay & {$[54]$} & 25 & $\begin{array}{l}18 \text { patients acute hamstring avulsion, } 7 \text { patients } \\
\text { chronic tears }\end{array}$ & $\begin{array}{l}92 \% \text { minimal or no pain, } 96 \% \text { estimated their } \\
\text { functional recovery to be greater than } 75 \% \\
\text { of the uninvolved limb, and } 88 \% \text { felt their } \\
\text { strength was greater than } 75 \% \text { of the uninvolved } \\
\text { limb. Subjects who were isokinetically tested more } \\
\text { than } 1 \text { year after surgery averaged } 98 \% \text { strength } \\
\text { compared to the uninvolved limb }\end{array}$ \\
\hline Folsom & {$[57]$} & 26 (athletes) & $\begin{array}{l}21 \text { patients acute hamstring avulsion, } 5 \text { patients } \\
\text { chronic tears }\end{array}$ & $\begin{array}{l}76 \% \text { percent of their patients returned to } \\
\text { sports.Overall, } 96 \% \text { of athletes reported good } \\
\text { leg control, and } 80 \% \text { of athletes were pain free }\end{array}$ \\
\hline Sarimo & {$[58]$} & 41 & Complete avulsions & $\begin{array}{l}\text { At an average of } 37 \text { months } 90 \text { excellent results, } \\
10 \text { were good, } 5 \text { were moderate, and } 7 \text { were poor. } \\
\text { Six of } 7 \text { poor results were in patients treated }>3 \\
\text { months post injury }\end{array}$ \\
\hline Wood & {$[59]$} & 71 & $\begin{array}{l}47 \text { complete retracted tears, } 16 \text { complete and } \\
\text { minimally retracted tears, } 7 \text { incomplete tears, } \\
1 \text { severe muscle-tendon rupture, } 1 \text { ischial } \\
\text { tuberosity avulsion }\end{array}$ & $\begin{array}{l}\text { At } 2 \text { years postoperatively } 84 \% \text { strength. } 80 \% \text { of } \\
\text { patients returned to their previous sporting } \\
\text { activities. There were statistically inferior } \\
\text { hamstring strength and endurance results in } \\
\text { patients with chronic retracted tears when } \\
\text { compared to the remaining patients }\end{array}$ \\
\hline Guanche & {$[61]$} & 15 & $\begin{array}{l}\text { Acute hamstring avulsion ( } 3 \text { patients), partial } \\
\text { hamstring avulsion ( } 9 \text { patients), ischial bursitis } \\
\text { ( } 3 \text { patients) }\end{array}$ & $\begin{array}{l}\text { One patient (with preoperative refractory ischial } \\
\text { bursitis) had recurrent ischial pain, } 2 \text { patients } \\
\text { complained of numbness over the posterior thigh } \\
\text { with resolution of their symptoms by } 6 \text { weeks } \\
\text { postoperatively }\end{array}$ \\
\hline
\end{tabular}

the nerve and avoid inadvertent injury. The tendinous origin is then inspected for any obvious tearing. A more inferior portal may then be created approximately $4 \mathrm{~cm}$ distal to the tip of the ischium and equidistant from the medial and lateral portals. This portal is employed either for insertion of suture anchors or suture management.

In Table 5 the available endoscopic results have been compared with published results obtained through open procedures. Although endoscopic treatment appears a good option in expert hands, at present there is just a single case series published in the literature. Therefore, more evidence is required if surgeons are to transfer more widely to endoscopic techniques.

\section{Conclusions}

Open surgery has been utilized for many years to address various extra-capsular pathologies of the hip. Endoscopic techniques have since evolved to treat internal snapping hip syndrome, iliopsoas impingement, AIIS impingement, external snapping hip syndrome, trochanteric bursitis, gluteus medius tears, piriformis syndrome and proximal hamstring diseases. Although the current evidence for these endoscopic techniques is limited to single case series, published results are encouraging. Excellent results are not reported in all patients with either open, arthroscopic or endoscopic procedures. There is consensus about the importance of accurate patient selection to achieve the best results. Further randomized studies would be necessary to justify the choice of arthroscopic or endoscopic procedures, perhaps based on comparability of success rates, complication rates and attendant advantages of day-case surgery.

\section{Conflict of interest None.}

Open Access This article is distributed under the terms of the Creative Commons Attribution License which permits any use, distribution, and reproduction in any medium, provided the original author(s) and the source are credited.

\section{References}

1. Larson CM, Guanche CA, Kelly BT, Clohisy JC, Ranawat AS (2009) Advanced techniques in hip arthroscopy. Instr Course Lect 58:423-436

2. Stevens MS, Legay DA, Glazebrook MA, Amirault D (2010) The evidence for hip arthroscopy: grading the current indications. Arthroscopy 26:1370-1383

3. Ilizaliturri VM Jr, Camacho-Galindo J, Evia Ramirez AN, Gonzalez Ibarra YL, McMillan S, Busconi BD (2011) Soft tissue pathology around the hip. Clin Sports Med 30:391-415

4. Byrd JW (2006) Evaluation and management of the snapping iliopsoas tendon. Instr Course Lect 55:347-355 
5. Shabshin N, Rosenberg ZS, Cavalcanti CF (2005) MR imaging of iliopsoas musculotendinous injuries. Magn Reson Imaging Clin N Am 13:705-716

6. Domb BJ, Shindle MK, McArthur B, Voos JE, Magennis EM, Kelly BT (2005) Iliopsoas impingement: a newly identified cause of labral pathology in the hip. HSS J 7:145-150

7. Taylor GR, Clarke NM (1995) Surgical release of the "snapping iliopsoas tendon'. J Bone Joint Surg Br 77:881-883

8. Jacobson T, Allen WC (1990) Surgical correction of the snapping iliopsoas tendon. Am J Sports Med 18:470-474

9. Dobbs MB, Gordon JE, Luhmann SJ et al (2002) Surgical correction of the snapping iliopsoas tendon in adolescents. J Bone Joint Surg Am 84:420-424

10. Gruen GS, Scioscia TN, Lowenstein JE (2002) The surgical treatment of internal snapping hip. Am J Sports Med 30:607-613

11. Hoskins JS, Burd TA, Allen WC (2004) Surgical correction of internal coxa saltans: a 20-year consecutive study. Am J Sports Med 32:998-1001

12. Ilizaliturri VM Jr, Chaidez C, Villegas P, Briseño A, CamachoGalindo J (2009) Prospective randomized study of 2 different techniques for endoscopic iliopsoas tendon release in the treatment of internal snapping hip syndrome. Arthroscopy 25:159-163

13. Anderson SA, Keene JS (2008) Results of arthroscopic iliopsoas tendon release in competitive and recreational athletes. Am J Sports Med 36:2363-2371

14. Flanum ME, Keene JS, Blankenbaker DG, Desmet AA (2007) Arthroscopic treatment of the painful "internal" snapping hip: results of a new endoscopic technique and imaging protocol. Am J Sports Med 35:770-779

15. Wettstein M, Jung J, Dienst M (2006) Arthroscopic psoas tenotomy. Arthroscopy 22:907.e1-4

16. Ilizaliturri VM Jr, Villalobos FE, Chaidez PA et al (2005) Internal snapping hip syndrome: treatment by endoscopic release of the iliopsoas tendon. Arthroscopy 21:1375-1380

17. Rajasekhar C, Kumar KS, Bhamra MS (2005) Avulsion fractures of the anterior inferior iliac spine: the case for surgical intervention. Int Orthop 24:364-365

18. Pan H, Kawanabe K, Akiyama H, Goto K, Onishi E, Nakamura T (2008) Operative treatment of hip impingement caused by hypertrophy of the anterior inferior iliac spine. J Bone Joint Surg Br 90:677-679

19. Larson CM, Kelly BT, Stone RM (2011) Making a case for anterior inferior iliac spine/subspine hip impingement: three representative case reports and proposed concept. Arthroscopy 27:1732-1737

20. Hetsroni I, Larson CM, Dela Torre K, Zbeda RM, Magennis E, Kelly BT (2012) Anterior inferior iliac spine deformity as an extra-articular source for hip impingement: a series of 10 patients treated with arthroscopic decompression. Arthroscopy 28: 1644-1653

21. Matsuda DK, Calipusan CP (2012) Adolescent femoroacetabular impingement from malunion of the anteroinferior iliac spine apophysis treated with arthroscopic spinoplasty. Orthopedics 35:e460-e463

22. Tortolani PJ, Carbone JJ, Quartararo LG (2002) Greater trochanteric pain syndrome in patients referred to orthopedic spine specialists. Spine J 2:251-254

23. Barnthouse NC, Wente TM, Voos JE (2012) Greater trochanteric pain syndrome: endoscopic treatment options. Oper Tech Sports Med 20:320-324

24. Ilizaliturri VM Jr, Camacho-Galindo J (2010) Endoscopic treatment of snapping hips, iliotibial band, and iliopsoas tendon. Sports Med Arthrosc 18:120-127

25. Krishnamurthy G, Connolly BL, Narayanan U, Babyn PS (2007) Imaging findings in external snapping hip syndrome. Pediatr Radiol 37:1272-1274
26. Lustenberger DP, Ng VY, Best TM, Ellis TJ (2011) Efficacy of treatment of trochanteric bursitis: a systematic review. Clin J Sport Med 21:447-453

27. Provencher MT, Hofmeister EP, Muldoon MP (2004) The surgical treatment of external coxa saltans (the snapping hip) by Z-plasty of the iliotibial band. Am J Sports Med 32:470-476

28. White RA, Hughes MS, Burd T (2004) A new operative approach in the correction of external coxa saltans. Am J Sports Med 32:1504-1508

29. Faraj AA, Moulton A, Sirivastava VM (2001) Snapping iliotibial band. Report of ten cases and review of the literature. Acta Orthop Belg 67:19-23

30. Fery A, Sommelet J (1988) The snapping hip. Late results of 24 surgical cases. Int Orthop 12:277-282

31. Govaert LHM, der Vis Van HM, Marti RK, Albers GH (2003) Trochanteric reduction osteotomy as a treatment for refractory trochanteric bursitis. J Bone Joint Surg [Br] 85-B:199-203

32. Ilizaliturri VM Jr, Martinez-Escalante FA, Chaidez PA, Camacho-Galindo J (2006) Endoscopic iliotibial band release for external snapping hip syndrome. Arthroscopy 22:505-510

33. Wiese M, Rubenthaler F, Willburger RE (2004) Early results of endoscopic trochanter bursectomy. Int Orthop 28:218-221

34. Baker CL Jr, Massie RV, Hurt WG (2007) Arthroscopic bursectomy for recalcitrant trochanteric bursitis. Arthroscopy 23:827-832

35. Fox JL (2012) The role of arthroscopic bursectomy in the treatment of trochanteric bursitis. Arthroscopy 18:E34

36. Bradley DM, Dillingham MF (1998) Bursoscopy of the trochanteric bursa. Arthroscopy 14:884-887

37. Farr D, Selesnick H, Janecki C, Cordas D (2007) Arthroscopic bursectomy with concomitant iliotibial band release for the treatment of recalcitrant trochanteric bursitis. Arthroscopy 23:905.e1-5

38. Kandemir U, Bharam S, Philippon MJ, Fu FH (2003) Endoscopic treatment of calcific tendinitis of gluteus medius and minimus. Arthroscopy 19:E4

39. Voos JE, Shindle MK, Pruett A, Asnis PD, Kelly BT (2009) Endoscopic repair of gluteus medius tendon tears of the hip. Am J Sports Med 37:743-747

40. Davies H, Zhaeentan S, Tavakkolizadeh A, Janes G (2009) Surgical repair of chronic tears of the hip abductor mechanism. Hip Int 19:372-376

41. Westacott DJ, Minns JI, Foguet P (2011) The diagnostic accuracy of magnetic resonance imaging and ultrasonography in gluteal tendon tears-a systematic review. Hip Int 21:637-645

42. Strauss EJ, Nho SJ, Kelly BT (2010) Greater trochanteric pain syndrome. Sports Med Arthrosc 18:113-119

43. Del Buono A, Papalia R, Khanduja V, Denaro V, Maffulli N (2012) Management of the greater trochanteric pain syndrome: a systematic review. Br Med Bull 102:115-131

44. Domb BG, Nasser RM, Botser IB (2010) Partial-thickness tears of the gluteus medius: rationale and technique for trans-tendinous endoscopic repair. Arthroscopy 26:1697-1705

45. Cassidy L, Walters A, Bubb K, Shoja MM, Shane Tubbs R, Loukas M (2012) Piriformis syndrome: implications of anatomical variations, diagnostic techniques, and treatment options. Surg Radiol Anat 34:479-486

46. Pecina HI, Boric I, Smoljanovic T, Duvancic D, Pecina M (2008) Surgical evaluation of magnetic resonance imaging findings in piriformis muscle syndrome. Skeletal Radiol 37:1019-1023

47. Filler AG, Haynes J, Jordan SE et al (2005) Sciatica of nondisc origin and piriformis syndrome: diagnosis by magnetic resonance neurography and interventional magnetic resonance imaging with outcome study of resulting treatment. J Neurosurg Spine 2:99-115

48. Fishman LM, Dombi GW, Michaelsen C, Ringel S, Rozbruch J, Rosner B, Weber C (2002) Piriformis syndrome: diagnosis, 
treatment, and outcome-a 10-year study. Arch Phys Med Rehabil 83:295-301

49. Benson ER, Schutzer SF (1999) Posttraumatic piriformis syndrome: diagnosis and results of operative treatment. J Bone Joint Surg Am 81:941-949

50. Martin HD, Shears SA, Johnson JC, Smathers AM, Palmer IJ (2011) The endoscopic treatment of sciatic nerve entrapment/ deep gluteal syndrome. Arthroscopy 27:172-181

51. Dezawa A, Kusano S, Miki H (2003) Arthroscopic release of the piriformis muscle under local anesthesia for piriformis syndrome. Arthroscopy 19:554-557

52. Hwang DS, Kang C, Lee JB, Cha SM, Yeon KW (2010) Arthroscopic treatment of piriformis syndrome by perineural cyst on the sciatic nerve: a case report. Knee Surg Sports Traumatol Arthrosc 18:681-684

53. Beltran L, Ghazikhanian V, Padron M, Beltran J (2012) The proximal hamstring muscle-tendon-bone unit: a review of the normal anatomy, biomechanics, and pathophysiology. Eur $\mathbf{J}$ Radiol 81:3772-3779

54. Sallay PI, Ballard G, Hamersly S (2008) Subjective and functional outcomes following surgical repair of complete ruptures of the proximal hamstring complex. Orthopedics 31:1092
55. De Smet AA, Blankenbaker DG, Alsheik NH, Lindstrom MJ (2012) MRI appearance of the proximal hamstring tendons in patients with and without symptomatic proximal hamstring tendinopathy. AJR Am J Roentgenol 198:418-422

56. Reurink G, Goudswaard GJ, Tol JL, Verhaar JA, Weir A, Moen MH (2012) Therapeutic interventions for acute hamstring injuries: a systematic review. Br J Sports Med 46:103-109

57. Folsom GJ, Larson CM (2008) Surgical treatment of acute versus chronic complete proximal hamstring ruptures: results of a new allograft technique for chronic reconstructions. Am J Sports Med 36:104-109

58. Sarimo J, Lempainen L, Mattila K (2008) Complete proximal hamstring avulsions: a series of 41 patients with operative treatment. Am J Sports Med 36:1110-1115

59. Wood DG, Packham I, Trikha SP (2008) Avulsion of the proximal hamstring origin. J Bone Joint Surg Am 90:2365-2374

60. Guanche CA (2012) Proximal hamstring syndrome: repair and ischial bursectomy. Oper Tech Sports Med 20:333-339

61. Dierckman BD, Guanche CA (2012) Endoscopic proximal hamstring repair and ischial bursectomy. Arthroscopy Techniques 1:e201-e207 